\title{
Amino Acid and Mineral Supplementation in Fermentation Process of Concentrate Protein of Jatropha Seed Cake (Jatropha Curcas L.)
}

\author{
Titin Widiyastuti and Tri Rahardjo Sutardi
}

\author{
Faculty of Animal Science, Jenderal Soedirman University Jl. Dr. Suparno Karangwangkal Puwokerto \\ Correspondent author email: dyast72@yahoo.com
}

\begin{abstract}
The purpose of this study is to assess the optimization of fermentation process by adding minerals and amino acids so that the potential of protein of Concentrate Protein-Jatropha seed cake (CP-JSC) can be optimally used as a substitute for soybean meal. The method used was completely randomized design. The treatment consisted of F1: Fermentation CP-JSC + methionine-lysine (0.25\%: 0.25\%), F2: Fermentation CP-JSC + methionine-lysine (0.5\%: 0.5\%), F3: F1 + 0.45\% Dicalcium Phosphate, F4: F2 + 0.45\% Dicalcium Phosphate. Each treatment was repeated four times, continued by Least Significant Difference (LSD), variables observed are the levels of antinutrients (phorbolester, antitrypsin), the levels of nutrients (fat, protein, crude fiber, Ca, P and gross energy) and amino acid. Results of analysis of variance showed that the addition of amino acids and minerals $\mathrm{Ca}, \mathrm{P}$ in the fermentation process highly significantly affected on the level of crude fiber and phosphor $(P<0.01)$ and significantly affected the gross energy content of CP-JSC post-fermentation $(P<0.05)$. Dry matter, crude protein, crude lipid and calcium were not affected by supplementation of methionine and lysine as well as calcium and phosphorus. Supplementation of methionine and lysine in the fermentation substrate showed good levels of essential amino acids and non-essential higher than previous studies although not statistically significant $(P>0.05)$. While the levels obtained phorbolester range of $0.055 \%-0.08 \%$. It was concluded that the optimization of fermentation can be done without adding the amino acid supplementation of minerals calcium and phosphorus. Supplementation significantly affect a significant increase or decrease in some nutrients (crude fiber, gross energy, phosphor) and capable of suppressing a decrease in amino acids. Supplementation of amino acids Lysine and Methionine $0.05 \%$ is the best treatment.
\end{abstract}

Key words: optimization, fermentation, minerals, amino acids, Concentrate Protein-Jatropha seed cake

Abstrak. Tujuan penelitian adalah mengkaji optimasi proses fermentasi CP-JSC dengan menambahkan mineral dan asam amino sehingga potensi protein CP-JSC dapat dimanfaatkan secara optimal sebagai pengganti bungkil kedelai dalam pakan. Metode yang digunakan adalah eksperimental dengan rancangan acak lengkap. Perlakuan terdiri atas F1 : Fermentasi CP-JSC + methionine-lysine (0,25\%:0,25\%), F2 : Fermentasi CP-JSC + methionine-lysine (0,5\%: 0,5\%), F3 : F1+ 0,45\% Dicalsium Phosphat, F4 : F2+ 0,45\% Dicalsium Phosphat. Setiap perlakuan diulang 4 kali, dilanjutkan dengan uji Beda Nyata Terkecil (BNT), Peubah yang diamati adalah kadar antinutrisi (phorbolester, antitrypsin), kadar nutrien (lemak, protein, serat kasar , Ca, P dan gross energi) dan asam amino. Hasil analisis variansi menunjukkan bahwa penambahan asam amino dan mineral $\mathrm{Ca}, \mathrm{P}$ pada proses fermentasi berpengaruh sangat nyata terhadap kadar serat kasar dan phosphor $(P<0,01)$ serta berpengaruh nyata terhadap kadar gross energi CP-JSC pasca fermentasi $(P<0,05)$. Sementara kadar nutrien yang lain (BK, protein kasar dan lemak kasar serta calcium) tidak dipengaruhi oleh suplementasi methionine dan lysine maupun calcium dan phosphor. Suplementasi methionine dan lysine pada substrat fermentasi menunjukkan kadar asam amino baik essensial dan non essensial yang lebih tinggi dibanding penelitian sebelumnya meskipun secara statistik tidak nyata $(P>0,05)$. Kadar phorbolester berkisar 0,055\% - 0,08\%. Disimpulkan bahwa optimasi fermentasi dapat dilakukan dengan suplementasi asam amino tanpa menambahkan mineral calcium maupun phosphor. Suplementasi berpengaruh nyata terhadap peningkatan maupun penurunan yang signifikan pada beberapa nutrien (serat kasar, gross energi, phosphor) serta mampu menekan penurunan asam amino. Suplementasi asam amino Lysin dan Methionin sebesar 0,05\% merupakan perlakuan yang terbaik.

Kata Kunci : Optimasi, Fermentasi, Mineral, Asam Amino, Protein Concentrate Bungkil Biji Jarak

\section{Introduction}

In order to support double consumption of poultry meat, strategic steps are needed to avoid a mere discourse without actual conduct.
Cattle productivity attributes are crucial as poultry meat production improves, meat supply for society is secured with affordable price. The affordable poultry products are inseparable with highly-efficient production. One of the 
efforts to improve production efficiency is optimizing the use of quality and relatively inexpensive feed. Through the exploration of jatropha seed cake as alternative protein source to substitute soybean meal or a part of fishmeal in feed, it is expected to solve the issue.

Optimizing jatropha seed cake as the new feed is viable when the limiting factors are eliminated or minimized. Several detoxification methods are widely used to eliminate the negative anti-nutrition effect of jatropha seed cake by thermal and chemical treatment (Aregheore et al., 2003; Herrera et al., 2005; Chivandi et al., 2006), adding sodium butyric acid in feed (Arnouts and Vandendriessche, 2007), precipitation technique in alkaline (Makkar et al., 2008). Previous study reported by Widiyastuti and Prayitno (2011) using lactic acid bacteria (Lactobacillus spp and Bifidobacter spp) and several additional saccharide (proceeded by FOS addition up to $1.5 \%$ has been done and applied to broiler and layer feed (Widiyastuti et al., 2013). Widiyastuti et al. (2014) reported that complete feed with fermented jatropha seed cake that is tolerable/safe for Rex rabbit ration is up to $12 \%$ but has not optimally improved production performance. Comprehensive strategy is needed to maximize potential protein in jatropha seed cake without disturbing poultry performance. Widiyastuti et al. (2015) reported that in the manufacture of protein concentrate of fermented jatropha seed cake (CP-JSCF), the optimum nutrient content, anti-nutrition and biological nutrient was the combined precipitation and fermentation using Lactobacillus acidophilus. This treatment showed the optimum nutrition performance with the lowest anti-nutrition $(P<0.01)$. However, essential amino acid (methionine and lysine) was still lower while $\mathrm{Ca}$ and $\mathrm{P}$ decreased after being used by Lactobacillus acidophyllus in growth along with the fermentation process. Optimizing fermentation process by supplementing amino acid and available mineral are needed to initiate and optimize the growth of Lactobacillus acidophyllus, to obtain the optimum CP-JSCF as the maximum substitute of jatropha seed cake. Nutrition enriched jatropha seed cake can be maximized through a proper processing method to obtain high quality feedstuff without disturbing the animal that consumed feed. In this research, optimizing fermentation process is important to maximize protein and other nutrient potential particularly essential amino acid for poultry, so CP-JSCF has balance or even higher nutrient than soy bean meal. Methionine and lysine supplementation and dicalcium phosphate in fermentation medium is expected to optimize fermentation process. Research objectives. This research was aimed to study the optimization of CP-JSC fermentation process using Lactobacillus acidophillus through amino acid and dicalcium phosphate supplementation to obtain concentrate protein with high biological value, and to investigate the quality of postprocessed jatropha seed quality (nutrition and anti-nutrition).

\section{Materials and Method}

\section{Research materials}

Lactobacillus acidophilus culture. MRS Broth and MRS Agar media, methionine, lysine, dicalcium phosphate (DCP), fresh cow milk as culture media for lactic acid bacteria, molasses, jatropha seed cake, pepsin, $0.1 \mathrm{M} \mathrm{HCl}, 0.1 \mathrm{M}$ $\mathrm{NaOH}, 1 \mathrm{M}$ acetate buffer $1 \mathrm{M} \mathrm{(pH} 4$ and 7), ethanol 95\%. pH meter, incubator, a set of analysis apparatus for nutrient and anti nutrient analysis.

\section{Research design}

Completely randomized design was $(4 \times 5)$ was applied to the research using fermentation optimization as treatments, including F1 : Fermentation CP-JSC + methionine-lysine (0.25\%: 0.25\%), F2 : Fermentation CP-JSC + methionine-lysine $(0.5 \%: 0.5 \%), \quad F 3: F 1+$ $0.45 \%$ Dicalcium Phosphate, F4 : F2+ $0.45 \%$ 
Dicalcium Phosphate. In case of significant effect, HSD test ensued (Smallest Difference). The observed variables were (1) nutrient level post fermentation (crude fat, crude protein, crude fiber, $\mathrm{Ca}, \mathrm{P}$, gross energy), and amino acid, and (2) Anti-nutrition content (phorbol ester, antitrypsin).

\section{Data analysis}

The obtained data were subject to analysis of variance (ANOVA), followed by Least Significant Difference (LSD) test for treatment effects observed to define the most optimum treatment (Steel and Torrie, 1993).

\section{Producing protein concentrate of jatropha seed cake (CP-JSC)}

This is the first stage to obtain protein concentrate of jatropha seed cake using sedimentation/precipitation according to Makkar et al. (2008) modified by Widiyastuti et al. (2012). Jatropha seed cake was soaked in Sodium Dodecyl Sulfat solution ( $0.346 \mathrm{~g}$ per liter aquadest) in 1:10 ratio, the mixture was blended for 5 minutes and let sit for 12 hours. The soaked jatropha seed cake in SDS solution was then filtered, and the sediment was submerged in aquadest in 1:10 ratio (of initial weight), added with $10 \% \mathrm{NaOH}$ to reach $\mathrm{pH} 11$, then stirred at $60^{\circ} \mathrm{C}$ for 30 minutes. The solution was let sit overnight. The submerged jatropha seed cake in $\mathrm{NaOH}$ was filtrated and the sediment was stored for analysis as residue, while the filtrate was precipitated with acid solution (thick $\mathrm{HCl}$ ) to reach $\mathrm{pH} 4$ while stirred slowly to obtain coagulation (protein sediment). Upon coagulation, oven drying ensued at $50-$ $60^{\circ} \mathrm{C}$.

\section{CP-JSC Fermentation}

(a) Revitalizing LAB culture. Lactobacillus acidophilus culture revitalized in MRS broth media was conducted by dissolving 50 gram media in $800 \mathrm{ml}$ liter aquadest and $200 \mathrm{ml}$ tomato extract. Sterilization took place at $121^{\circ} \mathrm{C}$ with $1 \mathrm{~atm}$ pressure for 15 minutes. Onehundred $\mu$ l pure culture was inoculated in new media and incubated at $37^{\circ} \mathrm{C}$ for $2 \times 24$ hour. (b) Making innoculum. MRS broth sterile media, as in revitalizing steps, started by creating inoculum that contained protein concentrate by preparing $2 \%$ sterile substrate of protein concentrate from MRS Broth plus 5\% carbohydrate source. Sterilization was at $121^{\circ} \mathrm{C}$, in $1 \mathrm{~atm}$ pressure for 15 minutes. The amount of inoculum used was $10 \%$ of substrate weight (Crueger and Crueger, 1984), then incubated at $37{ }^{\circ} \mathrm{C}$ for $2 \times 24 \mathrm{~h}$. Upon incubation, the starter for BBJ fermentation was ready. (c) Fermentation process. As much as 500 gram CPJSC, 5\% carbohydrate (molases) and methionine + lysine + DCP according to treatment were mixed, put into heat-resistant plastic bag, and sealed with $5-10 \mathrm{~cm}$ hard pipe and cotton ball. Autoclave sterilization was conducted at $121{ }^{\circ} \mathrm{C}$ under $1 \mathrm{~atm}$ pressure for 15 minutes. When temperature was below $40^{\circ} \mathrm{C}$, Lactobacillus acidophilus inoculum was added according to treatment then incubated at $37^{\circ} \mathrm{C}$ for $3 \times 24 \mathrm{~h}$ (Widiyastuti and Indradji, 2011). After incubation, CP-JSC fermentation was sampled to analyze the nutrient and anti-nutrition content under AOAC method (2005). Determining Trypsin inhibitor level was following Smith et al. (1980).

\section{Results and Discussion}

\section{Concentrate protein yield}

The amount of protein concentrate yield is attributed to several factors such as deoiled method (fatty acid elimination), denaturing substance concentrate, filtration process and so on. Protein denaturation includes the possible disorder and damage in secondary and tertiary protein structure. Denaturation is not strong enough to dissolve peptide bond where protein primary structure is unchanged after denaturation process. Denaturation occurs due to disorder in secondary and tertiary protein structure. In tertiary structure are four bonding interactions in side chain namely hydrogen 
bond, salt bridge, disulfide bond, and non-polar hydrophobic interaction that are likely to undergo disorder. Denaturation commonly found are precipitation and protein coagulation. Extraction and purification of vegetable proteins is mostly performed by alkaline extraction followed by an isoelectric precipitation. The protein concentrates or isolates have a protein content of $48-70 \%$ and 85-90\% (Moure et al., 2006).

The alkaline extraction of native proteins from Jatropha meal is scarcely investigated, since Jatropha has only recently been considered as a protein source. Previous studies report protein recovery of about 53-82 \% after alkaline extraction and isoelectric precipitation (Saetae et al., 2011; Makkar et al., 2008). Protein content in foodstuff generally determines the quality of the foodstuff. Nutrition value of foodstuf is not only determined by nutrient content but also the benefit for body (Muchtadi, 1989). One of the nutrition parameter for protein is digestibility or absorption efficacy of protein by the body (Del Valle, 1981). Based on the essential amino acids, foodstuff is deemed highly nutritious or otherwise. Highly nutritious foodstuff contains complete essential amino acid and the structure is relevant to body needs.

Digestible protein shows high amount of amino acids that body can digest and diversely. The contributing factors of protein digestibility are physical condition and chemical properties. The harder the foodstuff the lower digestibility due to the prominent complex bound in the materials. The bond can be intermolecular protein bond, protein - phytate bond and so on. Chemical properties are the anti-nutrition substances like tripsin inhibitor and phytate (Muchtadi, 1989).

\section{Protein concentrate of jatropha seed cake (CP- JSC) post-fermentation}

Protein concentrate of jatropha seed cake supplemented with amino acid, mineral, calcium and phosphor is presented in Table 1. Result showed that the highest and lowest nutrient concentrate of CP-JSC postfermentation was $88.10 \%$ (F2) - 86.92\% (F4) dry matter, $1.89 \%$ (F4) $-4.44 \%$ (F1) crude fiber, $49.97 \%$ (F3) - $50.34 \%$ (F1) crude protein, $16.84 \%$ (F3) - $18.11 \%$ (F2) crude fat, 4007 $\mathrm{kcal} / \mathrm{kg}(\mathrm{F} 2)-4190 \mathrm{kcal} / \mathrm{kg}(\mathrm{F} 1)$ gross energy, $0.46 \%(F 4)-0.50 \%$ (F3) calcium, and $0.37 \%$ (F4) $-0.62 \%(F 2)$ phosphor.

Table 1. Nutrient content of CP-JSC post- Fermentation

\begin{tabular}{lcccc}
\hline Nutrient & \multicolumn{4}{c}{ Treatments } \\
\cline { 2 - 5 } & F1 & F2 & F3 & F4 \\
\hline Dry matter (\%) & $86.46 \pm 38.74$ & $86.10 \pm 38.49$ & $86.89 \pm 38.93$ & $86.92 \pm 38.84$ \\
Crude fiber (\%) & $4.44 \pm 0.39^{\mathrm{a}}$ & $4.18 \pm 0.33^{\mathrm{a}}$ & $2.65 \pm 0.18^{\mathrm{b}}$ & $1.89 \pm 0.32^{\mathrm{c}}$ \\
Crude Protein (\%) & $50.34 \pm 0.95$ & $50.22 \pm 0.78$ & $49.97 \pm 0.80$ & $50.28 \pm 0.59$ \\
Crude Fat (\%) & $17.06 \pm 1.02$ & $18.11 \pm 0.62$ & $16.84 \pm 0.74$ & $17.69 \pm 0.10$ \\
Gross Energy & $4190 \pm 65.52^{\mathrm{a}}$ & $4007 \pm 81.11^{\mathrm{b}}$ & $4113 \pm 69.86^{\mathrm{ab}}$ & $4141 \pm 123.3162^{\mathrm{ab}}$ \\
(Kcal/kg) & $0.48 \pm 0.05$ & $0.47 \pm 0.07$ & $0.50 \pm 0.09$ & $0.46 \pm 0.09$ \\
Calcium (\%) & $0.48 \pm 0.10^{\mathrm{ab}}$ & $0.62 \pm 0.11^{\mathrm{b}}$ & $0.46 \pm 0.08^{\mathrm{ab}}$ & $0.37 \pm 0.07^{\mathrm{ac}}$ \\
Phospor (\%) & & & & \\
\hline
\end{tabular}

Description : F1 : Fermentation CP-JSC + methionine-lysine (0.25\%:0.25\%); F2 : Fermentation CP-JSC + methionine-lysine (0.5\% : 0.5\%); F3 : F1+ 0.45\% Dicalcium Phosphate; F4 : F2+ 0.45\% Dicalcium Phosphate. Values bearing equal superscript within raw is not significantly different $(P>0.05)$. 
Various nutrient content post-fermentation is comparable to result by Widiyastuti et al. (2015) that CP-JSC post fermentation with L.acidophilus without $\mathrm{N}$ substrate and mineral during fermentation contained $79.25 \%$ water, $12.56 \%$ crude fat, $1.31 \%$ crude fiber, $44.42 \%$ crude protein, $0.36 \%$ calcium, $0.43 \%$ phospor $4021 \mathrm{kcal} / \mathrm{kg}$ gross energy. It showed difference in the content of DM/water, fat, protein and crude fiber. Result also indicated a high protein content despite the high fat content.

Analysis of variance result showed that additional amino acid and $\mathrm{Ca}$ and $\mathrm{P}$ mineral in fermentation highly significantly affected crude fiber and phosphor content of CP-JSC post fermentation $(P<0.01)$, and significantly affected gross energy CP-JSC post fermentation $(P<0.05)$.

LSD test on crude fiber showed that crude fiber in $F 1$ was not different from that of $F 2$ $(P>0.05)$, but highly significantly different from that of F3 and F4 $(P<0.01)$. Treatment F2 highly significantly different from $\mathrm{F} 3$ and $\mathrm{F} 4(\mathrm{P}<0.01)$, while treatment $F 3$ was significantly different from F4 $(P<0.05)$.

Gross energy CP-JSC post fermentation from LSD result showed significant difference only in $F 1$ and F2 $(P<0.05)$, while other treatments were not significantly different $(P>0.05)$. It indicated that the increasing supplementation of amino acid, methionine and lysine actually decreased the energy level of CP-JSC post fermentation, while mineral supplement did not affect energy CP-JSC post fermentation.

LSD result showed that phosphor content in fermentation CP-JSC supplemented with methionine-lysine $0.25 \%: 0.25 \%$ (F1) was not different from that of other treatments (F2, F3, $F 4)(P>0.05)$. Difference across treatments was found in supplementation of methionine-lysine $0.5 \%: 0.5 \%(F 2)$ and methionine-lysine $0.5 \%$ : $0.5 \%+$ DCP $0.45 \%(F 4)(P<0.01)$. It indicated that high concentrate supplement of methionine and lysine and supplement of mineral calcium and phosphor in fact decreased phosphor content of CP-JSC post fermentation. In contrast, other nutrient content (DM, crude protein, crude fat and calcium) were not affected by methionine and lysine or calcium and phosphor supplementation.

\section{Anti-nutrition of protein concentrate of CP-JSC post fermentation}

Anti-nutrition observed in this research was phorbolester and antitrypsin. Phorbolester is diterpenoid tetracyclic generally known to cause tumor. Phorbolester imitates glycerol dialkyl (DAG), as protein kinase $\mathrm{C}$ activator that control different signal transduction and other cellular metabolic activity. Phrolboester are naturally prevalent in Euphorbiaceae and Thymelaeaceae. Biological activity of ester phorbol has a truly specific structure even in low concentrate, indicating toxicology manifest in animal consuming feed with phorbolester. The toxic limits the use of several nutritionenriched plants and agricultural waste as cattle feed due to ester phorbol content. Accordingly, several chemical and physical treatments have been evaluated to extract or ester phorbol is inactive, so the protein enriched-grains is compatible for feed source (Goel et al., 2007). Ester phorbol is defined as "polycyclic" substance where two hydroxyl groups in the closest atom carbon was esterified with fatty acid. Ahmed and Salimon (2009) indicated a significant variation in oil and ester phorbol content in jatropha seed from three countries; low ester phrobol in Malaysia jatropha seed oil (0.23\%), while in Indonesia and India is $1.58 \%$ and $0.58 \%$, respectively. Phorbol esters (PEs) are the major impediment to the wide commercial use of jatropha meal as a feedstock. During extraction of oil from jatropha seeds, 70 - 75\% of PEs goes with the oil, and $25-30 \%$ remains strongly bounded to the matrix of seed meal. Due to the high toxicity of PEs, seed cake cannot be used as animal feeds without detoxification Gogoi et al. (2014). Widiyastuti et al. (2015) reported that the lowest 
phorbolester in jatropha seed cake or 258 $\mathrm{mg} / \mathrm{kg}$ was in protein concentrate of postfermentation using L. acidophilus.

Table 2. Phorbolester and antitrypsin in CP-JSC Post Fermentation

\begin{tabular}{ccc}
\hline \multirow{2}{*}{ Treatments } & \multicolumn{2}{c}{ Anti-nutrition } \\
\cline { 2 - 3 } & $\begin{array}{c}\text { Phorbolester } \\
(\%)\end{array}$ & $\begin{array}{c}\text { Anti Trypsin } \\
\text { (TUI) }\end{array}$ \\
\hline F1 & $0.08^{\mathrm{a}}$ & $65453.44^{\mathrm{a}}$ \\
F2 & $0.055^{\mathrm{c}}$ & $68828.37^{\mathrm{a}}$ \\
F3 & $0.073^{\mathrm{ab}}$ & $36386.22^{\mathrm{b}}$ \\
F4 & $0.065^{\mathrm{b}}$ & $36230.72^{\mathrm{b}}$ \\
\hline
\end{tabular}

Values bearing equal superscript within columns is not significantly different $(P>0.05)$.

Result showed that the highest phorbolester was $0.08 \%$ in $\mathrm{F} 1$ (amino acid methionine and lysine $0.25 \%: 0.25 \%$ ) and the lowest was $0.055 \%$ in $\mathrm{F} 2$ (amino acid methionine and lysine $0.5 \%$ : $0.5 \%)$. This result was lower than $1.58 \%$ in jatropha seed oil from Indonesia (Ahmed and Salimon, 2009), but higher than that by Widiyastuti et al. (2015) assumedly due to high fat content of CP-JSC post-fermentation, but still lower than $0.86 \mathrm{mg} \mathrm{g}^{1}-1.48 \mathrm{mg} \mathrm{g-}{ }^{1}$. (Makkar et al. 2008). The treatments that reduced phorbol esters below $3 \mathrm{mg} / \mathrm{kg}$ treated residue (as 12-O-tetradecanoylphorbol-13acettate equivalent) could produce feeds that

Table 3. Amino acid of CP-JSC Post Fermentation may be considered safe for animal feeding (Makkar, 2016). While Gogoi et al. (2014) stated that the permissible limit of phorbol ester was $0.09 \mathrm{mg} / \mathrm{g}$. Antitrypsin level in this research was much higher than $1050.532 \pm 575.1024$ TUI post-fermentasi using $L$. acidophilus by Widiyastuti et al. (2015). This reseach showed that adding dicalsium phosphat (DCP) in the substrate of CP-JSC in fermentation process reduce anti trypsin content. It was no defferences among kind of $\mathrm{N}$ source (between soy bean meal and fish meal). Most protease inhibitors or anti trypsin are proteins with domains that enter or block a protease active site to prevent substrate access. According to protein content, there is no difference among treatments but Akande and Balogun (2009) reported that protein and trypsin inhibitor contents were negatively correlated.

\section{Amino acid of CP-JSC post fermentation}

Protein and amino acid supply is the most expensive component of poultry diets and it is for this reason that every effort is made by the industry to minimize the cost of the protein portion of the diet (Mulyantini et al., 2010). Amino acid protein concentrate of jatropha seed cake post fermentation is presented in Table 3.

\begin{tabular}{cccccc}
\hline AMINO ACID & F1 & F2 & F3 & F4 & R4 $^{*}$ ) \\
\hline Aspartic acid & 4.13 & 3.8975 & 3.7875 & 3.76 & 3.263 \\
Glutamic acid & 6.97 & 6.5925 & 6.6425 & 6.375 & 5.537 \\
Serine & 1.6925 & 1.6575 & 1.465 & 1.595 & 1.340 \\
Histidine & 1.4475 & 1.35 & 1.435 & 1.415 & 0.717 \\
Glycine & 1.9325 & 1.8075 & 1.7525 & 1.725 & 1.997 \\
Threopnine & 1.4875 & 1.445 & 1.41 & 1.3725 & 0.500 \\
Arginine & 4.4825 & 4.2775 & 4.455 & 4.2 & 3.277 \\
Alanine & 2.3375 & 2.21 & 2.1725 & 2.13 & 1.637 \\
Tyrosine & 1.5125 & 1.455 & 1.39 & 1.37 & 0.903 \\
Methionine & 0.935 & 0.9975 & 0.875 & 0.9875 & 0.650 \\
Valine & 2.7925 & 2.64 & 2.635 & 2.5275 & 1.880 \\
Phenilalanine & 2.1475 & 2.0525 & 2.04 & 1.935 & 1.927 \\
I-Leucine & 2.525 & 2.38 & 2.4025 & 2.285 & 1.733 \\
Leucine & 3.4125 & 3.2425 & 3.285 & 3.0925 & 2.330 \\
Lysine & 2.13 & 2.4525 & 1.855 & 2.3175 & 0.907 \\
\hline
\end{tabular}

${ }^{*}$ CP-JSC non supplemented fermentation (Widiyastuti et al., 2012) 
As comparison, Widiyastuti et al. (2015) reported decreasing amino acid in protein concentrate post-fermentation using $L$. acidophilus. However, methionine and lysine supplementation in fermentation substrate showed higher essential and nonessential amino acid. It indicated that lysine and methionine supplement could prevent the decreasing all amino acids post fermentation. The quality of post-fermentation protein concentrate on total amino acid basis is as follows.

Table 4. Total Amino acid of CP-JSC Post Fermentation

\begin{tabular}{cc}
\hline Treatments & Total Amino acid (\%) \\
\hline F1 & $39.94 \pm 1.19$ \\
F2 & $38.47 \pm 1.67$ \\
F3 & $37.60 \pm 1.31$ \\
F4 & $37.10 \pm 2.83$ \\
\hline
\end{tabular}

Total amino acid in this research showed decreasing trend as methionine and lysine supplementation increased. Increasing $\mathrm{Ca}$ and $\mathrm{P}$ mineral addition actually decreased total amino acid although amino acid and mineral supplement was not significantly affecting $(P>0.05)$ on statistical basis. Compared to Widiyastuti et al. (2015) reporting $38.607 \%$ total amino acid post fermentation using $L$. acidophilus, this research showed relatively higher total amino acid than F1 $(0.25 \%$ methionine and lysine), while higher methionine and lysine supplementation or $0.5 \%$ (F2) showed decrease, even mineral supplementation caused lower total amino acid. Parsons (2002) stated the effects of overprocessing on AA digestibility varied greatly among AA. With effects being greatest for lysine, intermediate for cystine and much less for methione. In addition to the reduced digestibility of lysine caused by autoclaving, the concentration of lysine in the oilseed meals decreased considerably.

\section{Conclusions}

Supplementing $0.05 \%$ lysine and methionine is the optimum treatment. Optimizing fermentation is viable through amino acid supplementation without additional calcium or phosphor due to phorbolester content as a major limiting factor in ussage of CP-JSC as a feedstuff. Supplementation significantly increased several nutrient content (crude fiber, gross energy, and phosphor) and prevented the decreased amino acid.

\section{References}

AOAC. 2005. Official Methods of Analysis of AOAC International. $18^{\text {th }}$ Ed. Published by: AOAC International. Maryland. USA.

Aregheore EM, K Becker and HPS Makkar. 2003. Detoxification of a toxic variety of Jatropha curcas using heat and chemical treatments, and preliminary nutritional evaluation with rats. S.Pac.J.Nat.Sci. $21: 50-56$

Arnouts S and Vandendriessche J. 2007. The Effect of lectin in Combination with sodium butyrate on the performance of broilers. INVE Technologies. Hoogveld 93. 9200 Dendermonde. Belgium

Chivandi E, KH Erlwanger, SM Makuza, JS Read and JP Mtimuni. 2006. Effects of dietary jatropha curcas meal on percent packet cell volume, serum glucose, cholesterol and triglyceride concentration and alpha- amylase activity of weaned fattening pigs. Res. J. of Anim. Vet. Sci. 1 (1): 18- 24.

Crueger W and A Crueger. 1984. Biotechnology: A Texbook of Industrial Microbiology. Science tech. Inc. Madison. USA.

Del Valle, FR. 1981. Nutritional Qualities of Soya Protein as Affected by Processing. JAOCS. 58: 519

Despal, N Sigit and P Hasanah. 2007. Nutrient content and digestibility in vitro detoxified jatropha seed cake (Jatropha curcas L.). In: Proceeding National Seminar AINI IV. ISBN 978979-16617.0-6.

Goel, G, HPS Makkar, G Francis, and K Becker. 2007. Phorbol Esters: Structure, Biological Activity, and Toxicity in Animals. International Journal of Toxicology. 26:279-288. DOI: $10.1080 / 10915810701464641$.

Gogoi, R, UK Niyogi and AK Tyagi. 2014. Reduction of phorbol ester content in jatropha cake using high energy gamma radiation. Journal of Radiation Research and Applied. Sciences. 7 ( 2014 ) p: 305-309

Herera MJ, P Siddhuraju, G Francis, GD Ortiz and K Becker. 2006. Chemical composition, toxic/antimetabolic constituens, and effects of different treatments on their levels, in four provenances of Jatropha curcas L. From Mexico. Food Chem. 96 p : 80-89.

Makkar HPS, AO Aderibigbe and K Becker. 1998. Comparative Evaluation of Non Toxic an Toxic 
varieties of Jatropha curcas for Chemical Composition, Digestibility, Protein Degradability and Toxic Factors. Food Chem. $62: 207-215$.

Makkar HPS and K Becker. 1999a. Plats toxins and detoxification methods to improve feed quality of tropical seeds - Review. Asian-Aust. J. Anim. Sci. 12 (3) : $467-480$.

Makkar HPS, G Francis and K Beckers. 2008. Protein concentrate from Jatropha curcas screw-pressed seed cake and toxic and anti-nutritional factors in protein concentrate. J. Sci of Food and Agric. 88: 9, 2008, pp. 1542-1548(7)

Makkar, HPS. 2016. State-of-the-art on detoxification of Jatropha curcas products aimed for use as animal and fish feed: A review. Animal Feed Science and Technology, Volume 222 p: 87 $-99$

Moure, A, J Sineiro, H Dominguez and JC Parajo. 2006. Functionality of oilseed protein products: a review. Food Res. Int. 39(9):945-963

Muchtadi, 1989. Evaluation of Food Nutritional Value. Ministry of Education and Culture InterUniversity General Centre Food and Nutrition, Bogor Agriculture University.

Mulyantini NGA, RL Ulrikus, WL Bryden, and X Li. 2010. Different Levels of Digestible Methionine on Performance of Broiler Starter. Animal Production 12(1): $6-11$.

Parsons, C.M. 2002. Digestibility and bioavailability of protein and amino acids in: Poultry Feedstuffs Supply, Composition and Nutritive Value. Edited by: JM Mc Nab and KN Boorman. Poultry Science Symposium Series vol 26. CABI Publishing. England.

Pasaribu T, E Wina, B Tangendjaja and S Iskandar. 2009. Performance of chicken fed with Jatropha seed cake (Jatropha curcas) physical and chemical process product. JITV 14(1): 11-18.

Saetae, D, T Kleekayai, V Jayasena, and W Suntornsuk. 2011. Functional properties of protein isolate obtained from physic nut (Jatropha curcas L.) seed cake. Food Sci. Biotechnol. 20(1): 29-37

Saono. 1986. Fermentation of Prawn Sell and Its Metabolit.

http://shodhganga.inflibnet.ac.in/bitstream/106 03/5908/5/05_chapter\%203.pdf. Accessed on 24 April 2013.

Siddhuraju UP. Becker, K. 2001b. Preliminary Nutritional evaluation of Mucuna Seed Meal (Mucuna pruriens var utilis) in Common Carp (Cyprinus carpio L.) : An Assesment by Growth Performance and Feed Utilisation. Aquaculture. 196: $105-123$.
Smith, C, WV Megen, L Twalfhoven and C Hitchcock. 1980. The determination of trypsin inhibitor levels in foodstuffs. Journal of the Science of Food and Agriculture. Vol. 31. P: $341-350$.

Akande, S R and M.O. Balogun. 2009. Genetic characterization of biochemical contents of pigeon pea (Cajanus cajan (L.) Millsp). Nutrition and Food Science. Vol. 39 Iss: 3, pp.260 - 267

Steel RGD and JH Torrie. 1993. Principle and Statistical Procedure of Biometric Approach. $2^{\text {nd }}$ Ed. PT Gramedia Pustaka Utama. Jakarta.

Timotius. 2010. Fermentation Asam Laktat. http://lordbroken.wordpress.com/2010/08/25/f ermentation-asam-laktat. Accessed on 24th April 2013.

Widiyastuti T and CH Prayitno. 2011. Microintestinal Environmental Manipulation Using lectin Jatropha Seed Meal as Attachment Media of Lactic Acid Bacteria and Its Influence On The haematological profile of Poultry. Proceeding ${ }^{2 n d}$ Internasional Seminar and ${ }^{8 \text { th }}$ Biannual Meeting AINI. UNPAD. Jatinangor.

Widiyastuti $T$ and $M$ Indradji. 2011. Study of Complete Feed made of fermented Jatropha seed cake and the effect on performance of weaned rabbit. In: Proceedings of National Seminar Development of Rural Resources and Local Wisdom, Research Center of Food Nutrition and Health. LPPM UNSOED, $23^{\text {rd }}-24^{\text {th }}$ November, 2011.

Widiyastuti T, TR Sutardi and M Indradji. 2012. Optimizing Protein Concentrate of Jatropha seed cake through the combined chemical and biological technique using $L A B$ and the utilization for rabbit feed. Research report. First year. Faculty of Animal Science UNSOED. Purwokerto.

Widiyastuti, T, CH Prayitno and N Iriyanti. 2013. Digestibility and Blood Metabolite Profiles of Chicken Fed Fermented Jatropha Seed Meal. Animal Production 15(2):98-105

Widiyastuti $\mathrm{T}, \mathrm{M}$ Indradji, $\mathrm{A}$ Wibowo and $\mathrm{R}$ Hendroko. 2014. Biorefinery of Jatropha Seed Cake by Lactid Acid Bacteria and the Effects on Hematological Profile of Rex Rabbit. Energy Procedia. 47 (2014). P: 290 - 294. DOI: 10.1016/J.Egypro.2014.01.227. ISSN: 1876 6102.

Widiyastuti, T., T,R, Sutardi and M. Indradji. 2015. Quality of Protein Concentrate from Jatropha curcas Seed Cake Produced by Chemical and Biological Processing. The 5th International Conference on Sustainable Animal Agriculture for Developing Countries October 27-30, 2015 Pattaya, Thailand www.saadc2015.com. 